\title{
RENCANA PENGEMBANGAN LAPANGAN GAS METANA BATUBARA DANGKAL (SHALLOW CBM) DI DAERAH IDA MANGGALA, RANTAU, KABUPATEN HULU SUNGAI SELATAN KALIMANTAN SELATAN
}

\author{
Basuki Rahmad ${ }^{\text {) }}$, Sugeng Raharjo ${ }^{2}$, Eko Widi Pramudiohadi ${ }^{3)}$, Ediyanto ${ }^{4)}$ \\ ${ }^{1,2,4)}$ Jurusan Teknik Geologi, Fakultas Teknologi Mineral UPN “Veteran”Yogyakarta \\ 3) Jurusan Teknik Perminyakan, Fakultas Teknologi Mineral UPN “Veteran”Yogyakarta \\ Correspending author email : __rahmad2004@yahoo.com; basukirahmad@upnyk.ac.id
}

\begin{abstract}
Abstrak
Potensi kandungan gas batubara (Gas Content) Idamanggala, Rantau, Kalimantan Selatan berkisar 6,72 $\mathrm{m}^{3} / \mathrm{ton}$. Sumberdaya gas batubara (Gas In Place/GIP) Rantau, Kalimantan Selatan 0,002 tcf (saturasi gas 90\%), kisaran kedalaman 50-150 meter. Gas Metana Batubara (GMB) diproduksi dengan cara terlebih dahulu merekayasa batubara sebagai reservoir agar diperoleh cukup ruang sebagai jalan keluarnya gas metana. Proses rekayasa diawali dengan memproduksi air (dewatering) agar terjadi perubahan keseimbangan mekanika. Setelah tekanan turun, gas batubara akan keluar dari matrik batubara. Gas metana kemudian mengalir melalui rekahan batubara dan akhirnya keluar menuju lubang sumur. Puncak produksi Gas Metana Batubara (GMB) bervariasi antara dua minggu sampai dengan tiga tahun.

Rencana pengembangan lapangan dimulai dari tiga tahun pertama dengan melakukan lima sumur pilot (pilot well). Pemboran pilot dilakukan untuk mengenal dimensi seam dan kualitasnya, baik secara lateral maupun vertikal. Apabila regulasi pemerintah sesuai dan memungkinkan untuk memulai pengembangan, maka pengembangan sumur produksi dapat dimulai pada tahun 2021.

Pengembangan Lapangan Gas Batubara Daerah Rantau Kalimantan Selatan diprioritaskan untuk kebutuhan pasar lokal yaitu kebutuhan tenaga listrik setempat baik industri maupun rumah tangga dan jika memungkinan dapat dialirkan melalui pipa untuk perusahaan gas negara.
\end{abstract}

Kata Kunci: gas content, gas in place, reservoir batubara, dewatering, pilot well.

\begin{abstract}
Potential of gas content in Idamanggala, Rantau, South Kalimantan is about 6,72 $\mathrm{m}^{3} /$ ton. Gas In Place in Rantau, South Kalimantan 0,002 tcf (90\% gas saturated), in 50-150 meter of depth. Coal Bed Methane (CBM) is produced by manipulate the coal as reservoir in order to obtain enough space for methane gas to flow. The manipulation is begin with dewatering in order to change the balance of mechanical. After the pressure is down, the coal bed methane gas flows from the coal matrix. Then methane gas passes through coal fracture and flow to the well. The peak production of Coal Bed Methane (CBM) is between two weeks until seven years.

The plan of development is begin with five pilot wells in three years. This pilot drilling is to detect seam dimension and the qualification, either laterally or vertically. The plan of development is going to begin in 2021 if government regulations is appropriate and enables to initiate the development.

The plan of development in Rantau, South Kalimantan is prioritated to suffice the demand of local market especially for electricity either for dwelling or to flow through the pipes for national gas company.
\end{abstract}

Keyword: gas content, gas in place, reservoir batubara, dewatering, pilot well. 


\section{RENCANA PENGEMBANGAN LAPANGAN GAS METANA BATUBARA DANGKAL (SHALLOW CBM) DI DAERAH IDA MANGGALA, RANTAU, KAB. HULU SUNGAI SELATAN KALIMANTAN SELATAN}

\section{Pendahuluan}

Gas Metana Batubara (GMB) sebagai salah satu sumber energi telah dikembangkan di berbagai negara yang memiliki sumberdaya batubara cukup signifikan sebagai salah satu usaha dalam mengembangkan energi alternatif. Pengembangan gas metana batubara di beberapa negara telah mencapai tahapan produksi seperti Amerika Serikat, Canada, Australia, China dan India. Pertumbuhan ekonomi dunia yang terus meningkat tentu diikuti dengan meningkatnya kebutuhan energi, sehingga banyak negara mulai melihat bahwa gas metana batubara sebagai sumber energi yang dapat diharapkan mampu mensuplai gas alam dalam jangka waktu yang lama. Pengembangan Gas Metana Batubara (GMB) di Indonesia sangat dimungkinkan mengingat Indonesia merupakan salah negara penghasil batubara. Beberapa hal yang mendukung pengembangan gas metana batubara di Indonesia salah satunya adalah kekayaan sumberdaya batubara Indonesia yang berlimpah, ketersediaan cadangan minyak dan gas bumi yang semakin berkurang. Kekayaan sumberdaya batubara Indonesia memungkinkan ditemukannya sumberdaya gas metana batubara yang potensial terutama di Sumatra dan Kalimantan. Sementara cadangan migas di Indonesia terus mengalami penurunan dan di lain pihak kebutuhan energi tersebut semakin bertambah, membuat pencarian energi alternatif pengganti minyak dan gas bumi merupakan keharusan yang tidak dapat ditunda lagi sehingga gas metana batubara dianggap sebagai salah pilihan yang dapat dikembangkan (Hadiyanto, et al., 2004).

Gas Metana Batubara (GMB) merupakan salah satu fraksi dari suatu lapisan batubara. Gas dalam batubara terdiri dari metana $\left(\mathrm{CH}_{4}\right)$, karbondioksida $\left(\mathrm{CO}_{2}\right)$, nitrogen $\left(\mathrm{N}_{2}\right)$ dan air $\left(\mathrm{H}_{2} \mathrm{O}\right)$. Gas Metana Batubara (GMB) sering disebut sebagai sweet gas karena memiliki hydrogen sulfida $\left(\mathrm{H}_{2} \mathrm{~S}\right)$ yang rendah. Berbeda dengan gas bumi konvensional yang terjadi dalam reservoir batupasir. Gas Metana Batubara (GMB) merupakan gas hidrokarbon non-konvesional yang bersumber dari batubara dan tersimpan dalam reservoir batubara (Gambar 1). Reservoir GMB sangat berbeda dengan reservoir minyak pada umumnya. Gas Metana Batubara (GMB) atau Coal Bed Methane (CBM) adalah gas yang tersimpan karena adsorpsi dalam mikropori batubara. Gas Metana Batubara tersimpan dalam batubara melalui proses yang disebut adsorption. $\mathrm{Gas}^{\mathrm{CH}_{4}}$ menempel pada mikripori batubara (matriks). Fracture atau rekahan pada batubara (cleats) dapat juga berisi gas bebas atau gas yang tersaturasi oleh air. Sistem ini disebut dengan Dual Porosity Reservoirs (dalam Kristadi, H.J., Dati, D.W., Lemigas, 2012).

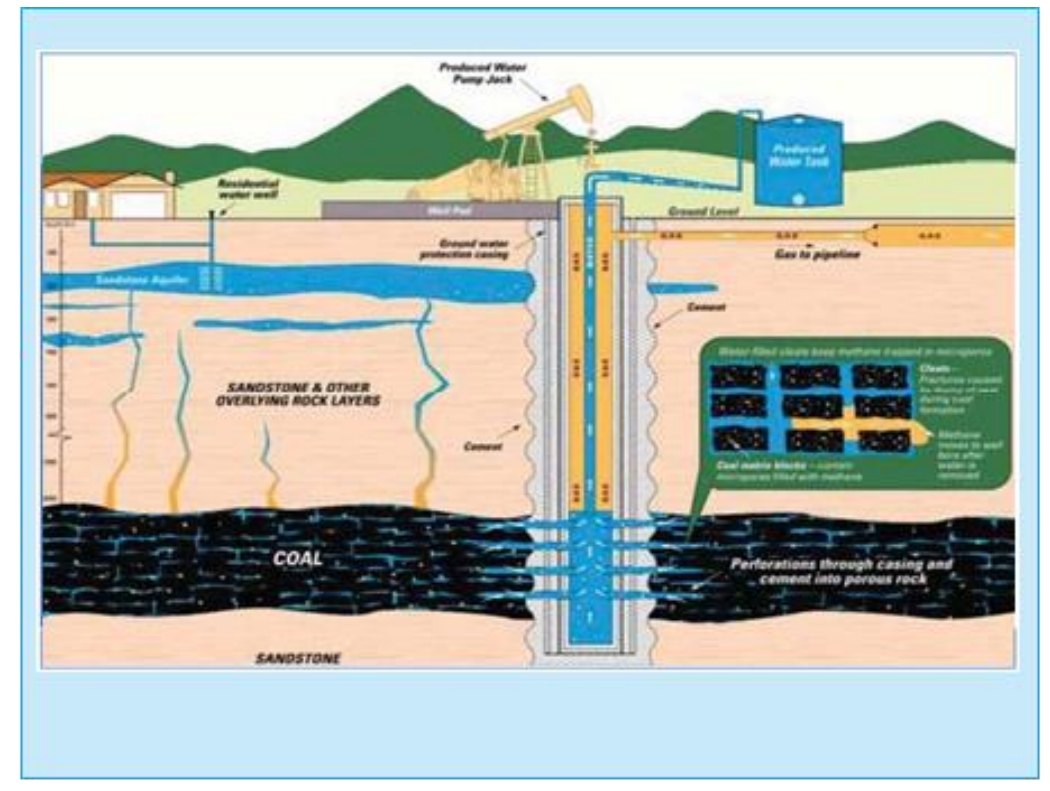

Gambar 1. Reservoir Gas Metana Batubara (dalam Kristadi, H.J., Dati, D.W., Lemigas, 2012) 
Karakteristik reservoir GMB memiliki perbedaan yang mendasar dibandingkan dengan sistem gas konvensional. Pada sistem GMB, batubara berfungsi sebagai batuan sumber (source rock) sekaligus sebagai reservoir gas. Batubara merupakan media berpori yang anisotropik dan heteregenous yang dicirikan oleh adanya dua sistem porositas yang berbeda (dual-porosity) yaitu macropores dan micropores. Macropores yang dikenal juga sebagai cleat yang umum dijumpai pada lapisan batubara, sedangkan micropore atau matrik adalah sebagai ruang simpan utama gas. Karakteristik yang unik tersebut membuat GMB diklasifikasikan sebagai tipe sumber gas nonkonvensional. Gambar 2 memperlihatkan perbedaan antara reservoir CBM dan reservoir konvensional gas.

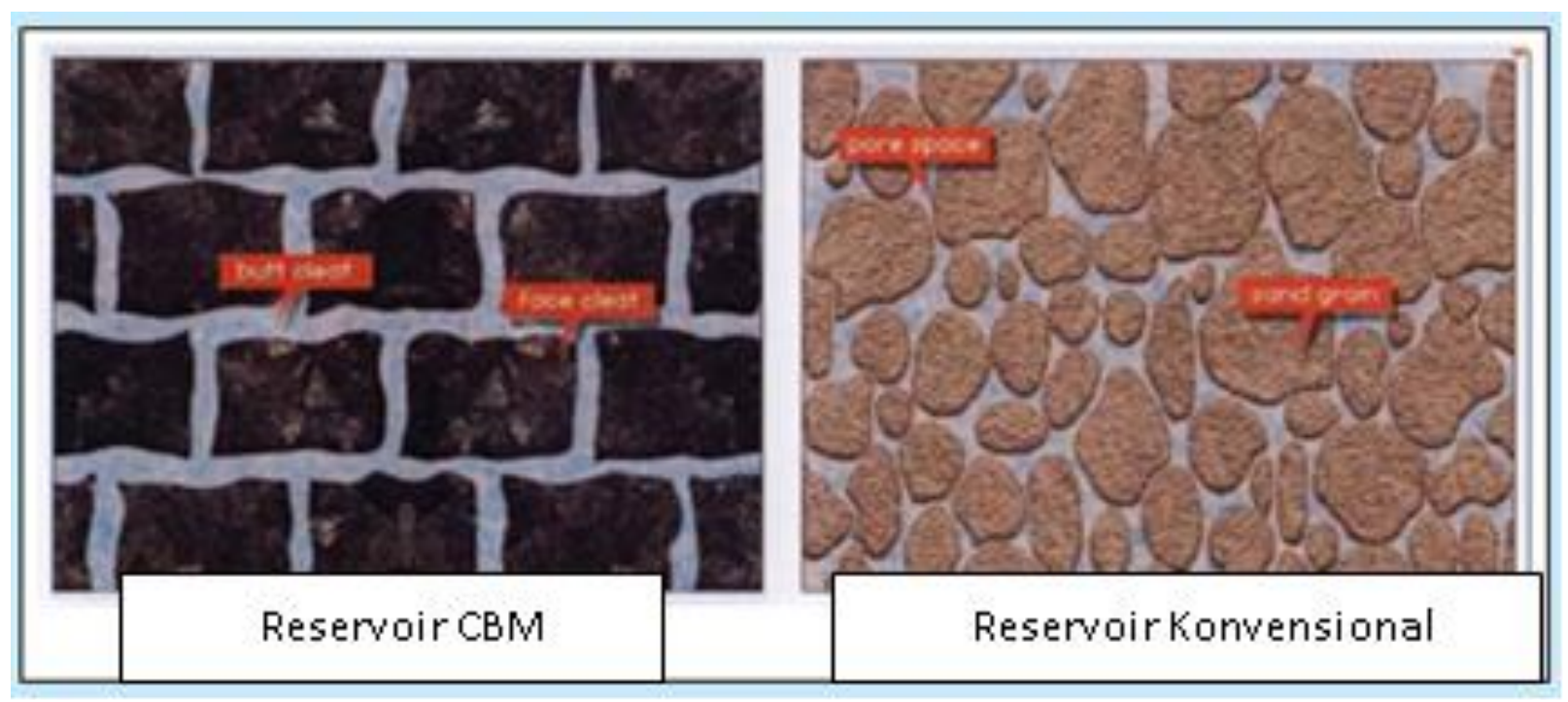

Gambar 2. Batuan Reservoir

(dalam Kristadi, H.J., Dati, D.W., Lemigas, 2012)

Sistem cleat adalah jejaring rekahan alami yang terbentuk pada batubara yang disebabkan oleh sifat kerapuhan batubara terhadap tekanan. Pemben-tukan rekahan pada batubara dipengaruhi oleh beberapa faktor yang meliputi proses litifikasi, dessication, pembatubaraan dan paleotektonik stress (Fraillon, 2000; Ayes, 2002). Dalam batubara berkembang dua jenis rekahan yang berpasangan dalam posisi orthogonal (berpotongan), yaitu face cleat dan butt cleat (Gambar $3)$. Secara umum keduanya berarah tegak lurus (perpendicular) terhadap bidang lapisan. Kenampakan face cleat dicirikan oleh bidang panjang yang sejajar dan menerus secara lateral, arah bidang tersebut sejajar dengan gaya tekanan maksimum serta tegak lurus dengan sumbu lipatan. Sedangkan butt cleats terbentuk kemudian sebagai akibat pelepasan gaya sesudah terbentuknya face cleat, dengan kenampakan bidangnya berpotongan secara tegak lurus dan menghubungkan bidang face cleat. Kerapatan cleat berhubungan dengan tingkat kematangan batu bara (rank), ketebalan lapisan, komposisi maseral dan kadar abu. Secara umum kerapatan cleat meningkat sesuai dengan tingkat kematangan batubara. Kerapatan cleat rata-rata dalam batubara dapat digolongkan menjadi 3 bagian, yaitu subbituminous $(2-15 \mathrm{~cm})$, high-volatile bituminous (0.3 to $2 \mathrm{~cm})$, dan medium - volatile bituminous $(<1 \mathrm{~cm})$ (Ayes, 2000; )). Namun kerapatan cleat juga meningkat pada batubara dengan ketebalan yang tipis, batubara yang kaya vitrinite dan batubara dengan kandungan abu yang rendah. Dalam pengukuran cleat selain parameter kerapatan juga dihitung lebar bukaan (aperture) dan konektivitas masing-masing face cleat. Pengamatan dan pengukuran cleat dalam batubara dilakukan dengan cara megaskopik (macro cleats) dan mikroskopik analisis (micro cleats and micropores). Cleat memiliki pengaruh yang besar pada permeabilitas berarah (directional permeability) dari batu bara yang sangat penting dalam eksploitasi GMB dalam rangka penentuan titik dan kerapatan sumur. 


\section{RENCANA PENGEMBANGAN LAPANGAN GAS METANA BATUBARA DANGKAL (SHALLOW CBM) DI DAERAH IDA MANGGALA, RANTAU, KAB. HULU SUNGAI SELATAN KALIMANTAN SELATAN}

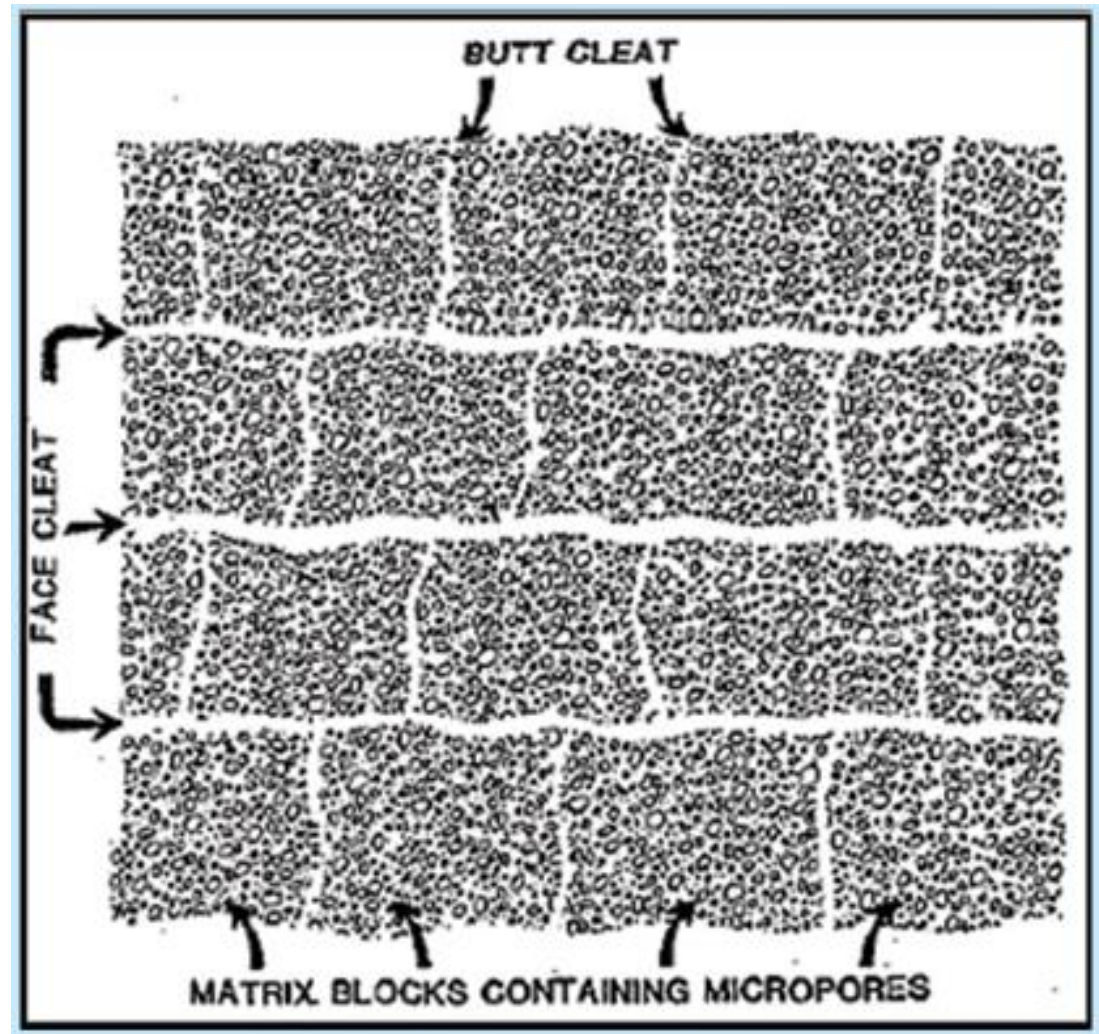

Gambar 3. Jenis dan Orientasi Cleat Batubara

(dalam Kristadi, H.J., Dati, D.W., Lemigas, 2012)

Gas $\mathrm{CH}_{4}$ yang terbentuk pada lapisan batubara merupakan hasil proses pembatubaraan yang terjadi akibat adanya aktivitas geologi berupa tekanan pembebanan (burial pressure) dan pemanasan oleh gradient temperatur serta diperkuat oleh adanya aliran panas dari aktivitas vulkanisme yang mengubah materi sellulosa menjadi batubara. Volume gas $\mathrm{CH}_{4}$ yang terbentuk dalam batubara akan meningkat sesuai dengan tingkat kematangannya (coal rank). Nilai kematangan tersebut tercermin dari nilai pengukuran Relectance Virinite (Rv) dan nilai kalori batubara. Secara umum ada 3 jenis gas metana, yaitu jenis thermogenic, biogenic dan campuran keduanya. Kedua tipe tersebut dapat dihasilkan dalam proses pembatubaraan. Secondary biogenic methane kemungkinan juga terbentuk sebagai akibat hasil reaksi aktivitas bakteri pada air tanah dalam cleat dengan batubara tingkat rendah (low-rank coal). Gas $\mathrm{CH}_{4}$ yang terbentuk kemudian tersimpan dalam batubara dengan beberapa cara sesuai dengan karakteristiknya (Fraillon, M., 2000) yaitu:

1) Sebagai gas bebas terbatas (limited free gas) yang tersimpan pada batubara di dalam

2) mikroporositas dan cleats,
3) sebagai gas larut dalam air yang terkandung dalam batubara,

4) sebagai gas serapan dan terikat secara molekuler pada partikel batubara,

5) mikroporositas, dan permukaan cleat,

6) sebagai gas serapan dalam struktur molekul batubara.

Batubara mempunyai kemampuan menampung gas lebih besar 3 - 4 kali dari pada reservoir konvensional. Hal tersebut disebabkan karena batubara mempunyai luas permukaan yang besar, yaitu 2.150 - $3.150 \mathrm{ft} 2 /$ gr. Gas yang tersimpan pada batubara teradsorbsi pada luasan permukaan molekul batubara dan pada cleat batubara. Kandungan gas pada batubara merupakan volume gas yang tersimpan dalam batu bara untuk tiap satuan massa batubara. Kandungan gas analogi dengan saturasi gas pada reservoir gas konvensional yang terimplementasi pada rumus perhitungan volume gas. Gas yang terkandung dalam batubara merupakan hasil dari coalification dan merupakan fungsi dari rank batubara yang diilustrasikan pada Gambar 4 yang menunjukkan bahwa rank batubara bituminous merupakan rank 
batu bara yang paling tinggi volume pembentukan gasnya (Lemigas, 2012).

Model transportasi gas pada reservoir GMB ditunjukkan pada Gambar 5 yang dimulai terlepas- nya gas dari permukaan dengan kondisi terserap pada partikel batubara akibat terjadinya penurunan tekanan kemudian berdifusi pada pori mikro dan diteruskan dengan aliran laminer pada sistem cleat.

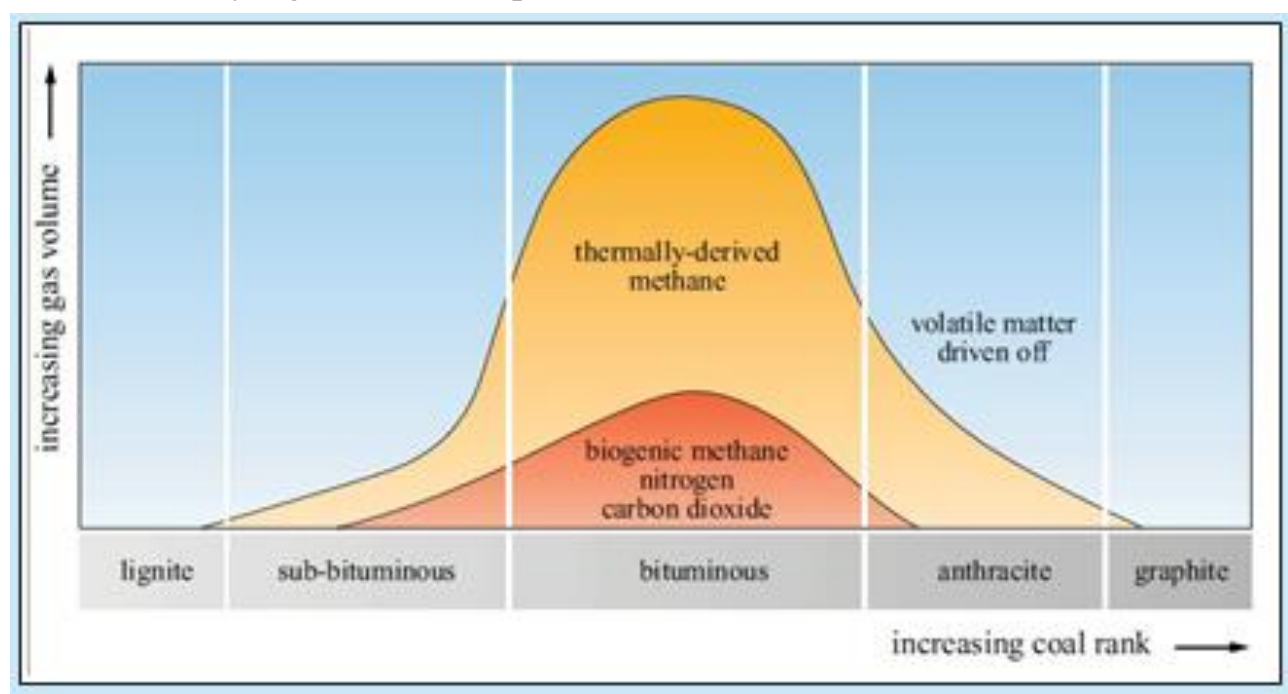

Gambar 4. Volume Gas Batubara Sebagai Fungsi Rank Batubara (dalam Kristadi, H.J., Dati, D.W., Lemigas, 2012)

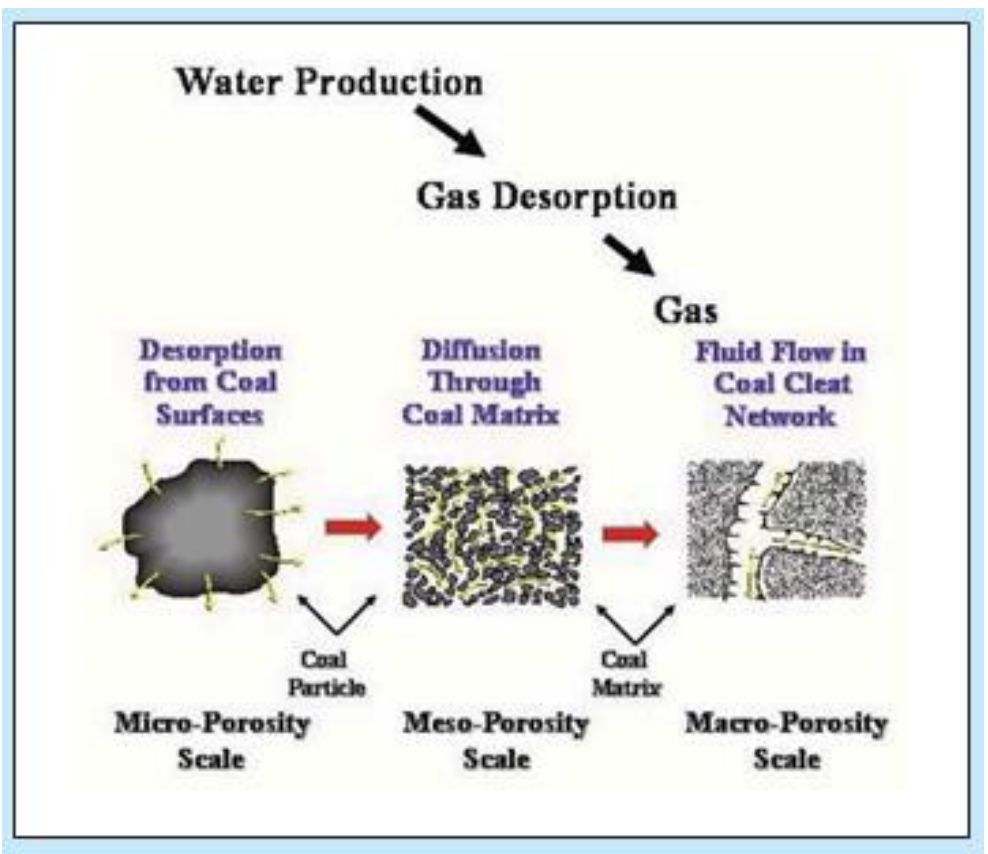

Gambar 5. Mekanisme Aliran Gas Dalam Batubara (dalam Kristadi, H.J., Dati, D.W., Lemigas, 2012)

Penelitian ini bertujuan untuk merencanakan pengembangan lapangan gas metana batubara di daerah Idamanggala, Kota Rantau dan sekitarnya, Kabupaten Hulu Sungai Selatan, Kalimantan Selatan (Gambar 6), sebagai proses tindak lanjut dari penelitian sebelumnya yang telah dilakukan yaitu analisis komposisi maseral, perhitungan nilai reflektan vitrinite $(\mathrm{Rv})$, analisis proksimat (moisture, kandungan abu, volatile matter dan fixed karbon) sehingga diperoleh kandungan gas (Gas Content) dan sumberdaya gas metana batubara (Gas In Place). 


\section{RENCANA PENGEMBANGAN LAPANGAN GAS METANA BATUBARA DANGKAL (SHALLOW CBM) DI \\ DAERAH IDA MANGGALA, RANTAU, KAB. HULU SUNGAI SELATAN \\ KALIMANTAN SELATAN}

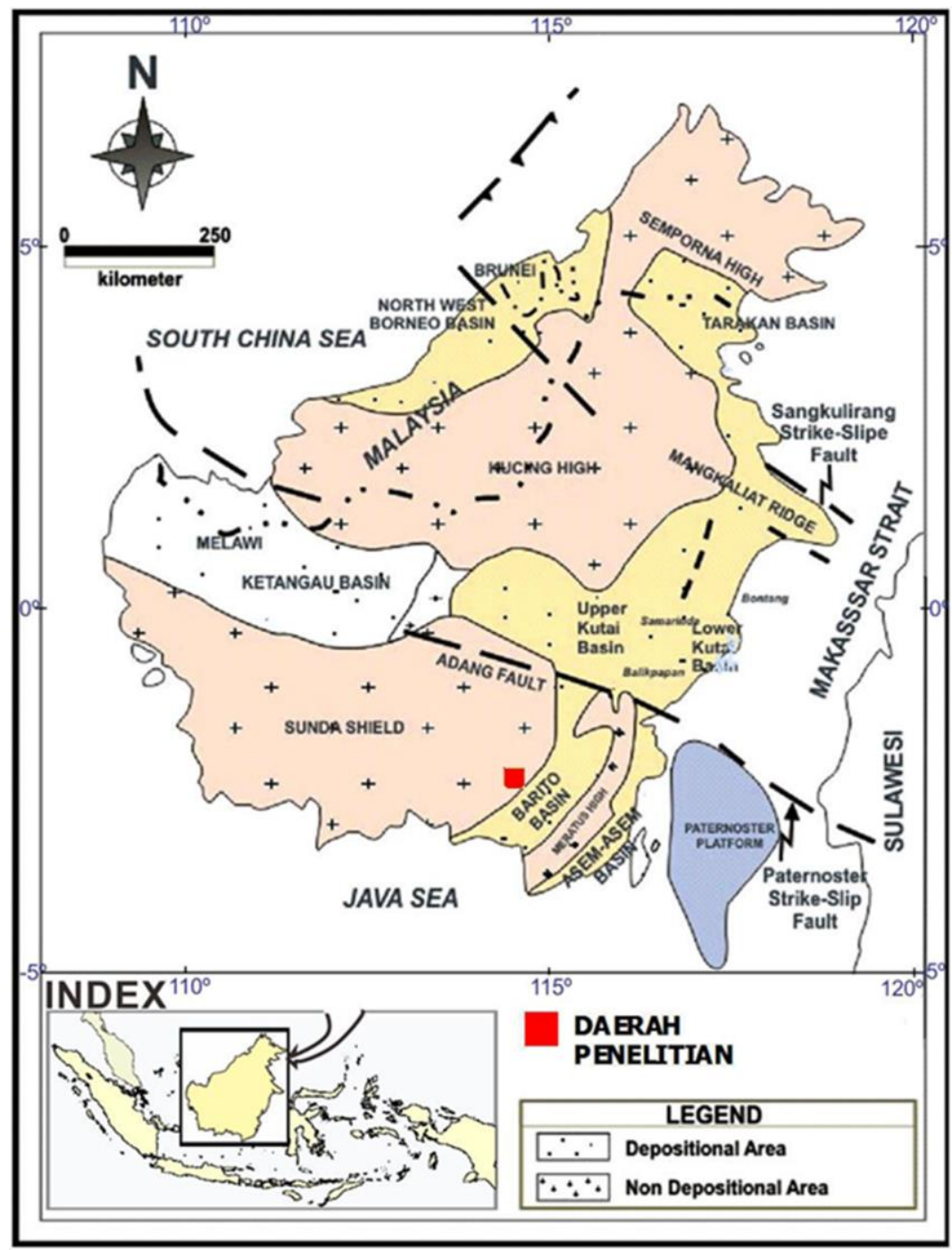

Gambar 6. Lokasi Daerah Penelitian terhadap Elemen-Elemen Tektonik Regional (Ott, 1987)

\section{Metode Penelitian}

Penelitian ini dilakukan di wilayah penambangan batubara di daerah Rantau dan sekitarnya. Metode penelitian yang dilakukan di lapangan adalah pengamatan batubara dan pengambilan contoh serta pengambilan data infrastruktur untuk perencanaan pengembangan.

Target utama seam batubara adalah Seam M-10 dengan luas wilayah sebarannya 150 ha, pada Formasi Warukin pada kedalaman $50-150$ meter. Sumberdaya tonase batubara Seam M-10 Formasi Warukin sebesar 76.800.000 ton (Basuki Rahmad, dkk., 2017).

Metoda pengambilan conto batubara dilakukan langsung di singkapan dinding tambang batubara pada seam M-10 dengan metode ply by ply, berdasarkan kenampakan lithotype secara makroskopis. Selanjutnya masing-masing conto direduksi ukurannya, dan dilakukan komposit kemudian dibagi menjadi dua untuk arsip dan analisis laboratorium.

Pekerjaan analisis di laboratorium meliputi :

a. Analisis proksimat batubara

b. Analisis mikroskopis batubara untuk mengidentifikasi komposisi maseral, mineral dan nilai reflektan vitrinite. Conto batubara yang diambil inti berupa bor kemudian dipreparasi untuk sayatan poles. Dalam preparasi conto diperlukan beberapa alat dan bahan seperti:

1. Sampel batubara

2. Bubuk resin (transoptic powder) 
3. Alat penumbuk

4. Ayakan ukuran 16, 20, dan 65 mesh

5. Cetakan polished briquette, pemanas, termometer, dan penekan

6. Alat pemoles (grinder-polisher)

7. Silicon carbide ukuran 800 dan 1000 mesh dan alumina oxide ukuran 0,$3 ; 0,05 ;$ dan 0,01 mikron

\section{Kaca preparat dan lilin malam}

Conto batubara yang diperoleh dari inti bor direduksi secara coning and quartering untuk mendapatkan jumlah conto yang sesuai untuk kebutuhan analisis. Selanjutnya conto batubara digerus secara manual dan diayak dengan menggunakan ayakan ukuran 16 mesh dan 20 mesh, fraksi ukuran butiran batubara -16 mesh +20 mesh yang diperoleh digunakan untuk analisis petrografi batubara.

Batubara fraksi ukuran -16 mesh +20 mesh tersebut kemudian dicampur dengan bubuk resin (transoptic powder) dengan perbandingan 1:1. Campuran selanjutnya dimasukkan ke dalam cetakan dan dipanaskan sampai suhu $200^{\circ} \mathrm{C}$. Setelah suhu mencapai $200^{\circ} \mathrm{C}$ pemanas dimatikan dan cetakan diberi tekanan sampai 2000 psi. Briquette dapat dikeluarkan setelah temperatur mencapai suhu kamar. Tahap berikutnya adalah pemolesan briquette yang dimulai dengan pemotongan menggunakan alat pemoles (grinderpolisher) kemudian dihaluskan dengan silicon carbide ukuran 800 mesh dan 1000 mesh di atas permukaan kaca. Selanjutnya dipoles dengan menggunakan alumina oxide ukuran 0,3 mikron, 0,05 mikron, dan terakhir ukuran 0,01 mikron di atas kain sutera atau silk cloth. Sayatan poles yang dihasilkan diletakkan di atas kaca preparat dengan dudukan lilin malam kemudian dilakukan levelling. Pengamatan sayatan poles dilakukan dengan menggunakan mikroskop reflektan baik secara kualitatif maupun kuantitatif untuk menentukan kandungan maseral maupun mineral dalam batubara. Penelitian mikroskopik menggunakan sinar pantul dengan pembesaran 200 kali dengan pengamatan sebanyak 500 titik.

Proses analisis dilaksanakan di Laboratorium Petrografi Batubara, Puslitbang tekMIRA, Bandung. Klasifikasi Maseral Batubara menggunakan standar Australia (AS 2856, 1986) dan mikroskop yang digunakan adalah Microscope Spectrophotometer Polarization with Fluorescence, tipe: MPM 100, merk : Zeiss.

Dalam penelitian ini peneliti menemukan rembesan gas metana yang keluar ke permukaan di lokasi penelitian dapat dilihat pada Gambar 7.

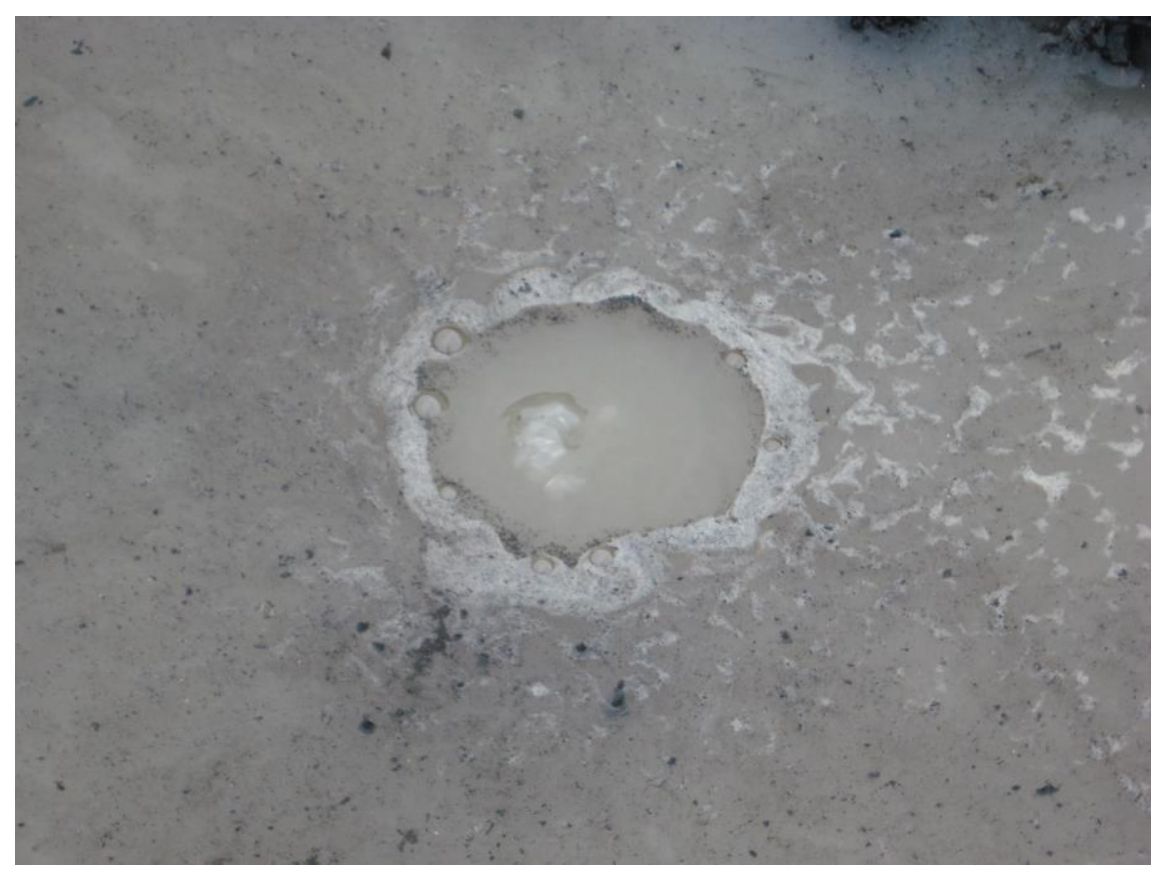

Gambar 7. Rembesan Gas Dari Seam Batubara Daerah Rantau Kalimantan Selatan (Basuki Rahmad, dkk., 2017) 


\section{Hasil Uji Laboratorium dan Sumberdaya Gas Metana}

\subsection{Uji Kualitas Batubara (Analisis Proksimat)}

Uji kualitas batubara untuk menentukan peringkat batubara adalah berdasarkan analisis proksimat batubara. Hasil analisis proksimat (kualitas batubara) berdasarkan contoh singkapan untuk setiap formasi ditunjukkan pada tabel 1(Basuki Rahmad, dkk., 2017.
Rata-rata kualitas batubara Formasi Warukin : Nilai Kalori 5966 kkal/kg (adb), CV 6218 kkal/kg (adb), sulfur 0,24\% (adb); abu 3,92\% (adb); inherent moisture 13,81\% (adb); volatile matter $36,57 \%$ (adb); fixed carbon 44,02\% (adb), Total Moisture 36,31 \% (Ar); relative density 1,28. Reflektan vitrinite random 0,4-0,58. Klasifikasi tingkatan batubara : sub-bituminus (Tabel 1).

Tabel 1. Hasil Uji Kualitas Batubara Seam M-10 (Basuki Rahmad, dkk., 2017)

\begin{tabular}{|c|c|c|c|c|c|c|c|c|c|c|c|c|}
\hline No. & Nomor Lab & Tanda Contoh & Formasi & Air Total & $\begin{array}{c}\text { Air } \\
\text { Lembab }\end{array}$ & Abu & $\begin{array}{c}\text { Zat } \\
\text { Terbang }\end{array}$ & $\begin{array}{l}\text { Karbon } \\
\text { Padat }\end{array}$ & $\begin{array}{l}\text { Nilai } \\
\text { Kalor }\end{array}$ & $\begin{array}{c}\text { Belerang } \\
\text { Total }\end{array}$ & \multirow[b]{2}{*}{$\begin{array}{l}\text { Relative } \\
\text { Density }\end{array}$} & \multirow[b]{2}{*}{$\operatorname{Rv}(\max )$} \\
\hline \multirow[t]{2}{*}{ No. } & Lab. Number & Sample Marks & Formation & $\begin{array}{c}\text { Total } \\
\text { Moisture }\end{array}$ & $\begin{array}{l}\text { Moisture } \\
\text { in Air } \\
\text { dried } \\
\text { sample }\end{array}$ & Ash & $\begin{array}{l}\text { Volatile } \\
\text { Matter }\end{array}$ & $\begin{array}{l}\text { Fixed } \\
\text { Carbon }\end{array}$ & $\begin{array}{c}\text { Calorific } \\
\text { Value }\end{array}$ & $\begin{array}{l}\text { Total } \\
\text { Sulfur }\end{array}$ & & \\
\hline & & & & $\% . \operatorname{Ar}$ & $\%, a d b$ & $\%, a d b$ & $\%$, adb & $\%, a d b$ & $\%$, adb & $\%, a d b$ & & \\
\hline 1 & $\mathrm{M}-10(1)$ & IDAMANGGALA & WARUKIN & 44.86 & 15.60 & 1.35 & 41.95 & 41.10 & 5498 & 0.93 & 1.26 & 0.34 \\
\hline 8 & $\mathrm{M}-10(2)$ & IDAMANGGALA & WARUKIN & 35.47 & 15.37 & 2.25 & 40.41 & 41.97 & 5720 & 0.52 & 1.30 & 0.58 \\
\hline 9 & M-10 (3) & IDAMANGGALA & WARUKIN & 18.98 & 11.72 & 0.88 & 44.13 & 43.27 & 6314 & 0.18 & 1.26 & 0.45 \\
\hline 10 & $\mathrm{M}-10(4)$ & IDAMANGGALA & WARUKIN & 5.53 & 3.12 & 6.97 & 44.47 & 45.44 & 7340 & 2.51 & 1.27 & 0.56 \\
\hline \multicolumn{4}{|c|}{ STANDART ACUAN } & $\begin{array}{l}\text { ASTM } \\
\text { D.3302 }\end{array}$ & $\begin{array}{l}\text { ASTM } \\
\text { D. } 3173\end{array}$ & $\begin{array}{l}\text { ASTM } \\
\text { D. } 3174\end{array}$ & ISO 562 & $\begin{array}{l}\text { ASTM } \\
\text { D. } 3172\end{array}$ & $\begin{array}{c}\text { ASTM D. } \\
5865\end{array}$ & $\begin{array}{l}\text { ASTM } \\
\text { D. } 4239\end{array}$ & $\begin{array}{c}\text { AS } 1038: \\
21\end{array}$ & \\
\hline
\end{tabular}

\subsection{Komposisi Maseral Batubara}

Hasil analisis mikroskopis batubara Formasi Warukin, Daerah Idamanggala seluruh sampel tersebut diambil dari data singkapan batubara di dinding tambang batubara (Basuki Rahmad, dkk., 2017). Rata-rata persentase grup-maseral vitrinite Formasi Muara Wahau 78\%, rata-rata Rv (random) $=0,45 \%$ (rank: sub-bituminus).
Pembentukan Gas Metana Formasi Warukin, Daerah Idamanggala, Daerah Rantau, Kalimantan Selatan masih dalam Tahap Gas Biogenik, artinya gas tersebut merupakan hasil dari aktifitas bakteri dalam $\mathrm{CO}_{2}$, dimana metabolisme methanogens (bakteri anaerobik) menggunakan $\mathrm{H}_{2}$ dan $\mathrm{CO}_{2}$ untuk mengkonversi acetate menjadi metana $\left(\mathrm{CH}_{4}\right)$. Maseral vitrinite Formasi Warukin terbagi menjadi Kelompok maseral Vitrinite, Liptinite dan Inertinite (Tabel 2); (Gambar 8).

Tabel 2. Hasil Analisis Mikroskopis (Maseral) Batubara Rantau (Basuki Rahmad, dkk., 2017)

\begin{tabular}{|c|c|c|c|c|c|}
\hline $\begin{array}{c}\text { No } \\
\text { Sampel }\end{array}$ & $\begin{array}{c}\text { Total Vitrinite (\% } \\
\text { vol) }\end{array}$ & $\begin{array}{c}\text { Total } \\
\text { Liptinite (\% } \\
\text { vol) }\end{array}$ & $\begin{array}{c}\text { Total } \\
\text { Inertinite } \\
\text { (\% vol) }\end{array}$ & $\begin{array}{c}\text { Total Mineral } \\
\text { Matter (\% vol) }\end{array}$ & $\begin{array}{c}\text { Reflektan } \\
\text { Vitrinit (\% } \\
\text { vol) }\end{array}$ \\
\hline 1 & 74,0 & 1,2 & 22,8 & 2,0 & 0,34 \\
\hline 2 & 74,8 & 7,6 & 16,2 & 1,4 & 0,58 \\
\hline 3 & 73,0 & 9,4 & 16,2 & 1,4 & 0,45 \\
\hline 4 & 80,2 & 1,6 & 15,8 & 2,4 & 0,56 \\
\hline
\end{tabular}



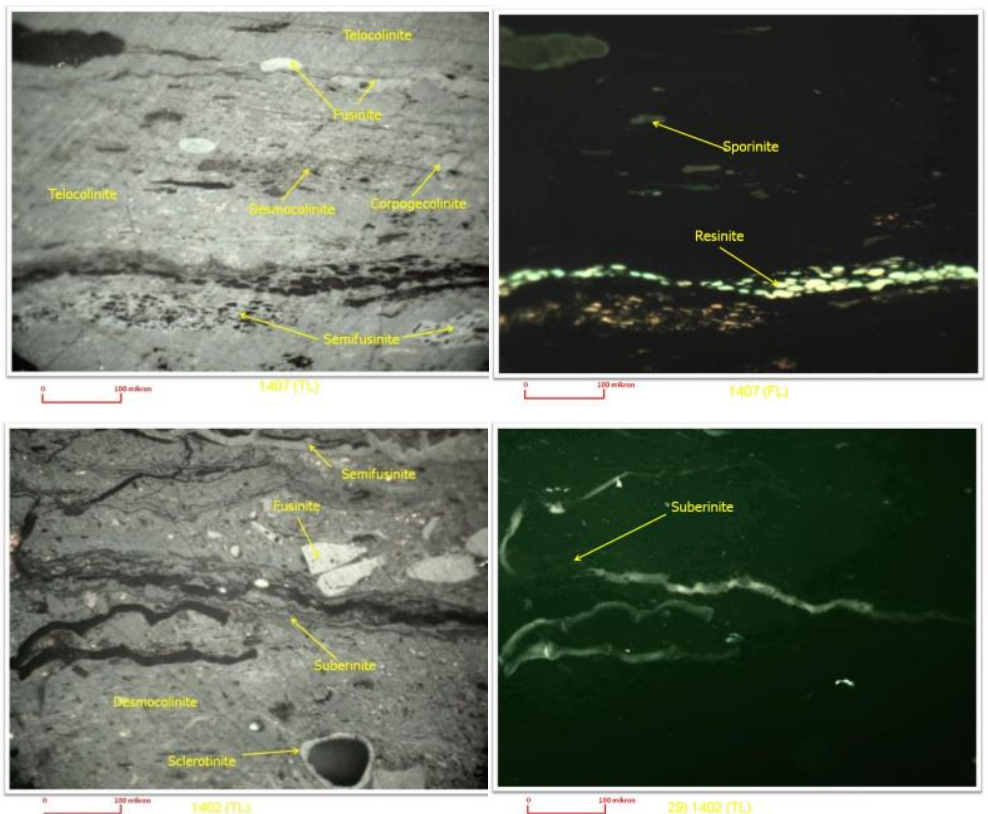

Gambar 8. Kenampakan Mikroskopis Batubara Idamanggala, Rantau,Kalimantan Selatan (Basuki Rahmad, dkk., 2017)

\subsection{Perhitungan Kandungan Gas dan Sumberdaya Gas (Gas In Place)}

Kandungan gas (Gas content) dihitung berdasarkan data yang diambil dari analisis proksimat pengambilan sampel batubara permukaan di Daerah Idamanggala, Rantau, Kalimantan Selatan.
Hasil analisis tersebut dipakai sebagai parameter untuk menghitung gas content dengan pendekatan persamaan Kim sebagai berikut (Basuki Rahmad, dkk., 2017):

$$
G c=\left(1-V_{M}-V_{A}\right) \times 0.2 \times\left\{k_{0} \times 0.096 h^{n_{0}}-0.14(3.24 h / 100)+24\right\}
$$

$\begin{array}{lll}\text { Ash Content } & \mathrm{V}_{\mathrm{A}}=64.94 \times \rho_{\mathrm{B}}-66.27 & \mathrm{~V}=\mathrm{Gas} \text { Content } \mathrm{Ft}^{3} \text { gas } \text { ton } \\ \text { Fixed Carbon } & \mathrm{V}_{\mathrm{FC}}=-0.517 \mathrm{~V}_{\mathrm{ASH}}+51.2 & \mathrm{k}_{0}=0.8 \times\left(\mathrm{V}_{\mathrm{FC}} / \mathrm{V}_{\mathrm{M}}\right)+5.6 \\ \text { Moisture } & \mathrm{V}_{\mathrm{M}}=-0.10 \mathrm{~V}_{\mathrm{ASH}}+4.61 & \mathrm{n}_{0}=0.39-0.1 \times\left(\mathrm{V}_{\mathrm{FC}} / \mathrm{V}_{\mathrm{M}}\right) \\ \text { Moisture Matter } & \mathrm{V}_{\mathrm{VM}}=100-\mathrm{V}_{\mathrm{A}}-\mathrm{V}_{\mathrm{FC}}-\mathrm{V}_{\mathrm{M}} & \mathrm{h}=\text { Depth in meters }\end{array}$

Besaran kandungan gas ini memberikan besarnya Gas In Place (GIP) dari sumberdayanya. Hasil perhitungan kandungan gas dapat dilihat di Tabel 3.

Kajian Perhitungan Sumberdaya Gas Metana Batubara (Gas In Place) Formasi Warukin di Daerah Idamanggala, Rantau, Kalimantan Selatan.

Rumus yang digunakan dalam perhitungan gas di tempat (Gas In Place/G.I.P.) adalah :

$\mathrm{GIP}=(\mathrm{A} * \mathrm{~h}) * \mathrm{Gc} * \mathrm{D} *$ Sgas

Ketererangan: A: area; h: tebal batubara; Gc: Gas Content; D: density coal; Sgas: Saturasi gas
Maka hasil perhitungan Gas In Place (GIP) Daerah Idamanggala, Rantau,Kalimantan Selatan dengan Kedalaman 50 - 150 meter, Saturasi Gas 90\%, Peringkat batubara sub-bituminous coal.

Kandungan Gas (Gas Content) batubara Rantau berkisar 5,77 - 6,72 m3/ton.

Sumberdaya (Gas In Place) gas metana batubara dengan saturasi gas 90\% adalah: 0,000183 tcf 0,00072 tcf pada kedalaman 50-150 meter.

Total sumberdaya gas metana batubara (Gas In Place) Daerah Idamanggala, Rantau, Kalimantan Selatan 0,002 tcf. 
Tabel 3. Hasil Perhitungan Kandungan Gas Batubara berdasarkan Uji

Kualitas Batubara Daerah Rantau, Kalimantan Selatan

(Basuki Rahmad, dkk., 2017)

\begin{tabular}{|c|c|}
\hline Kedalaman (m) & $\begin{array}{c}\text { Kandungan Gas/Gas } \\
\text { Content }\left(\mathbf{m}^{3} / \text { ton }\right)\end{array}$ \\
\hline 50 & 4,77 \\
\hline 100 & 4,93 \\
\hline 150 & 5,06 \\
\hline
\end{tabular}

\section{Produksi Gas Metana Batu bara}

Gas Metana Batu bara (GMB) diproduksi dengan cara terlebih dahulu merekayasa batubara sebagai reservoir agar diperoleh cukup ruang sebagai jalan keluar gas metana. Proses rekayasa diawali dengan memproduksi air (dewatering) agar terjadi perubahan keseimbangan mekanika. Setelah tekanan turun, gas batu bara akan keluar dari matrik batubara. Gas metana kemudian mengalir melalui rekahan batubara dan akhirnya keluar menuju lubang sumur. Puncak produksi GMB bervariasi antara 2 minggu sampai dengan 7 tahun. Sedangkan periode penurunan produksi lebih lambat dari gas bumi konvensional. Produksi GMB mempunyai multiguna antara lain dapat dijual langsung sebagai gas bumi, dijadikan energi dan sebagai bahan baku industri termasuk kebutuhan rumah tangga (Lemigas, 2013).

Produksi GMB sangat dipengaruhi oleh fracture system, fracture spacing dan fracture connection. Porositas dan permeabilitas dari fracture menyebabkan gas terproduksi ke lubang sumur. Pada awalnya sistem berada dalam kesetimbangan (equilibrium), pada cleat biasanya tersaturasi oleh $100 \%$ air kemudian gas tersimpan di dalam matrik yang airnya tidak dapat masuk ke dalamnya, biasanya di dalam matrik berupa embun 1-5\% (Nikola Marinic, 2004 dalam Lemigas 2013). Guna memproduksi gas, maka air harus diproduksikan dari dalam batubara untuk menurunkan tekanan reservoir. Suatu lapisan batubara dapat dimodelkan sebagai sebuah sistem fracture yang memiliki gas metana yang terserap di dalam matrik batu bara tersebut, seperti yang ditunjukkan pada Gambar 9.

Untuk memproduksikan gas metana dilakukan dengan menurunkan tekanan pada fracture melalui proses dewatering yang menyebabkan terjadinya proses desorbtion gas metana dari permukaan fracture batubara menuju ke dalam rongga fracture. Gas tersebut berasal dari matrik batu bara yang telah terdifusi menuju permukaan fracture. Selama memproduksikan gas dari dalam batubara, terdapat 3 phase yang terjadi atau dilalui oleh gas metana.

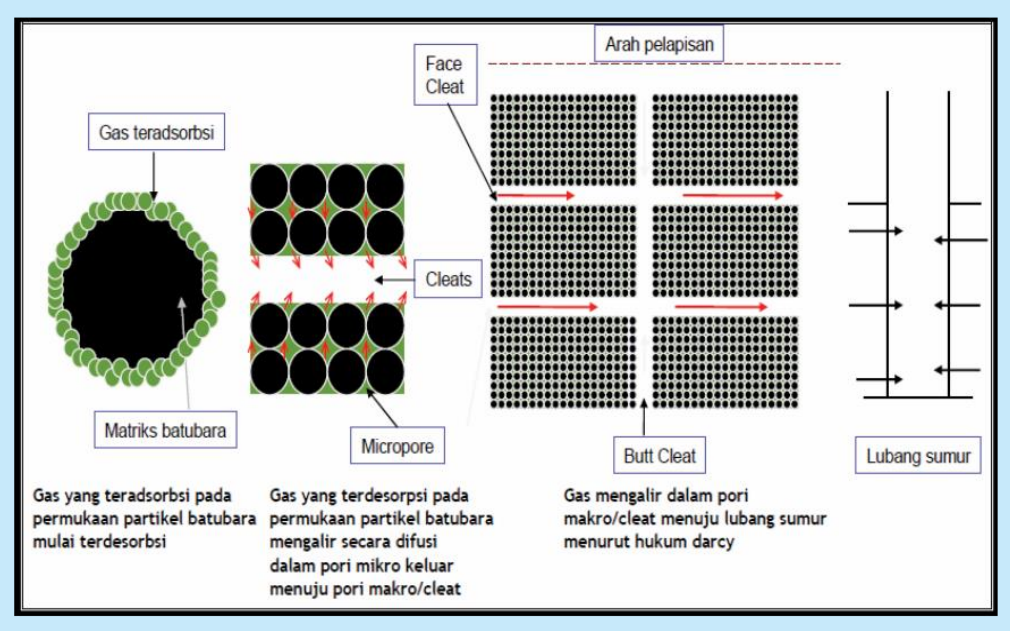

Gambar 9. Skema Proses Keluarnya Gas Metana dari Batubara 
(dalam Kristadi, H.J., Dati, D.W., Lemigas, 2012)

Perilaku kurva produksi GMB sangatlah berbeda dengan kurva produksi reservoir konvensional. Pada tahap awal produksi gas sangat dipengaruhi oleh produksi air yang berada di fracture di dalam reservoir yang juga mengontrol aliran fluida ke dalam sumur. Air di dalam reservoir harus diproduksikan terlebih dahulu untuk menurunkan tekanan reservoir agar terjadi perbedaan tekanan antara matrix dan fracture. Berikut adalah kurva produksi gas dan air yang terlihat pada Gambar 10.

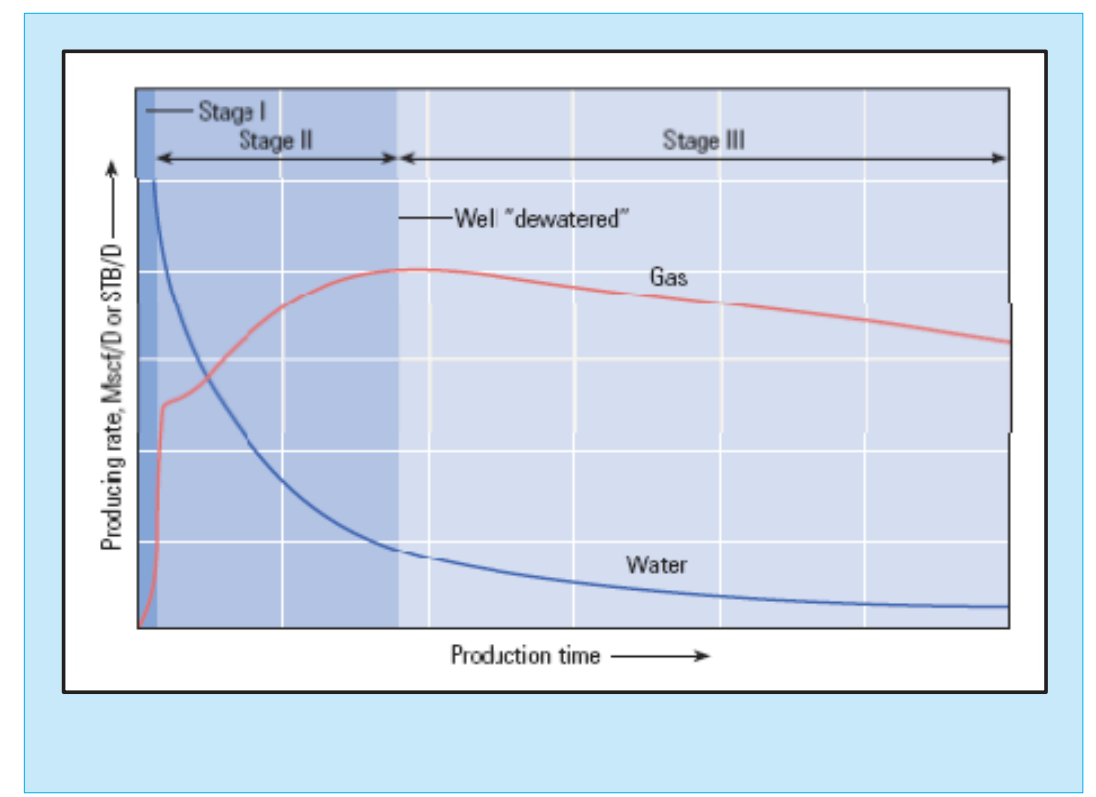

Gambar 10. Tiga Fase Kurva Produksi Air dan Gas

(dalam Kristadi, H.J., Dati, D.W., Lemigas, 2012)

Fase I: dicirikan oleh laju produksi air konstan dan tekanan reservoir mulai menurun. Selama phase ini, sumur dalam kondisi dipompakan untuk meningkatkan laju produksi gas. Biasanya laju gas akan meningkat, tergantung permeabilitas relatif di sekitar lobang bor.

Fase II: dicirikan oleh negative decline atau penurunan secara drastis laju produksi air. Pada phase ini alirannya berada pada kondisi dinamis (selalu berubah-ubah) tergantung dari:

- Penurunan permeabilitas relatif air

- Kenaikan permeabilitas relatif gas

- Efek outer boundary sudah mulai terasa (alirannya Preudo steady state)

- Laju produksi gas berubah menjadi dinamis.

Fase III: dimulai pada saat kondisi aliran di dalam reservoir mulai stabil, sumur telah mencapai peak gas rate, dan produksi gas menunjukkan kecenderungan menurun (decline). Selama fase ini produksi air rendah dan permeabilitas air dan gas berubah menjadi kecil, alirannya tetap Preudo steady state.

\subsection{Rencana Pengembangan (Plan of Development) Lapangan Gas Metana Daerah Idamanggala, Rantau, Kaliman Selatan}

Rencana pengembangan lapangan tersebut dimulai dari 3 tahun pertama dengan melakukan 5 (lima) sumur pilot (Gambar 11 dan 12). Pemboran pilot tersebut untuk mengenal dimensi seam dan kualitasnya, baik secara lateral maupun vertikal. Jadwal perencanaan pengembangan lapangan tersebut dapat dilihat pada Tabel 4. Besarnya sumberdaya Gas In Place gas batubara di wilayah studi bersama perlu dilakukan studi geologi dan pilot well. Tujuan eksplorasi ini untuk mengetahui volume gas, kualitas gas, kualitas air, jumlah lapisan batubara, penyebaran batubara, dan produktifitas sumur. 


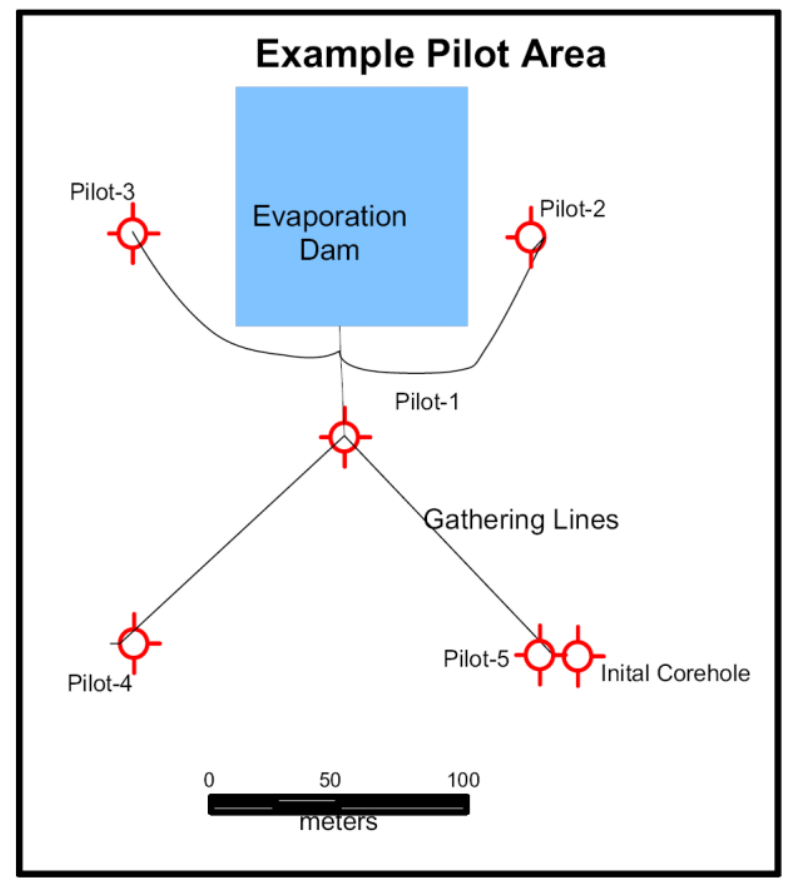

Gambar 11. Desain rencana Lima Pemboran Pilot (Pilot Well)

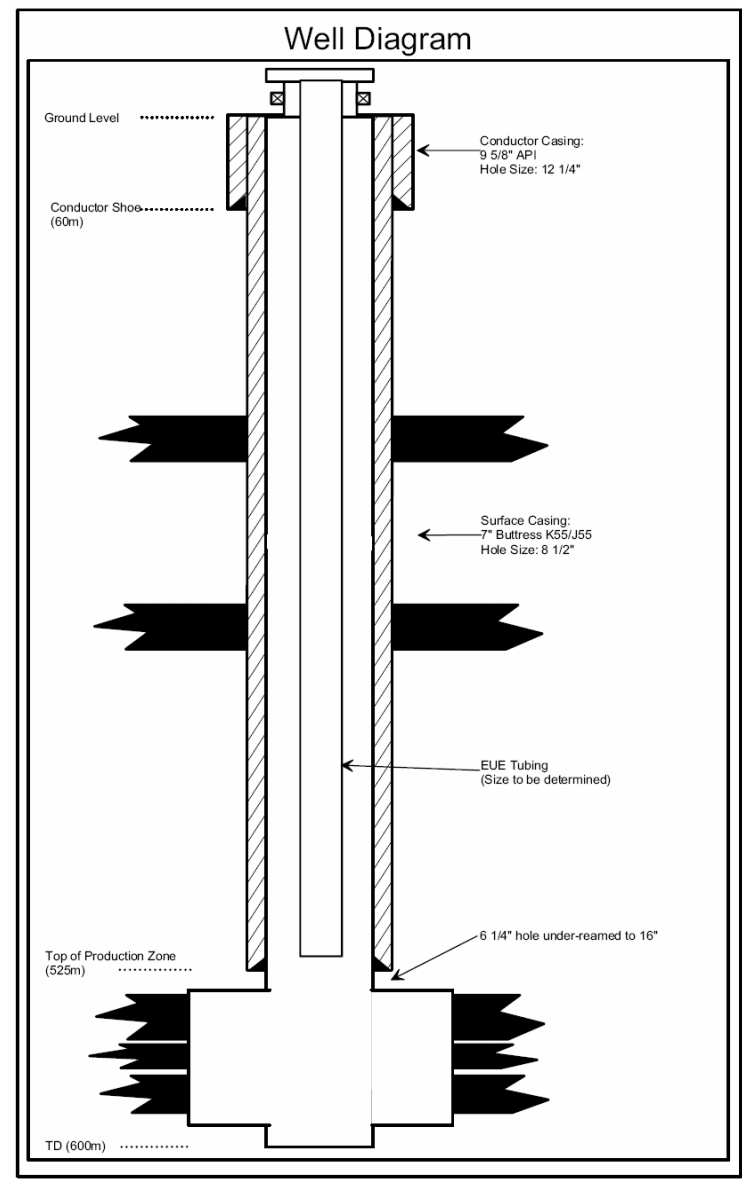

Gambar 12. Desain Pilot Well

(dalam Kristadi, H.J., Dati, D.W., Lemigas, 2012) 
Tabel 4. Jadwal Percepatan Pengembangan Lapangan Gas Metana Daerah Rantau, Kalimantan

\begin{tabular}{|c|c|c|c|c|c|c|c|c|c|c|c|c|c|c|c|c|c|c|c|c|}
\hline \multicolumn{21}{|c|}{ Rencana Pengembangan Gas Metana Batubara Daerah Rantau Kalimantan Selatan } \\
\hline & \multicolumn{4}{|c|}{2019} & \multicolumn{4}{|c|}{2020} & \multicolumn{4}{|c|}{2021} & \multicolumn{4}{|c|}{2022} & \multicolumn{4}{|c|}{2023} \\
\hline & Q1 & Q2 & Q3 & Q4 & Q1 & Q2 & Q3 & Q4 & Q1 & Q2 & Q3 & Q4 & Q1 & Q2 & Q3 & Q4 & Q1 & Q2 & Q3 & $\mathrm{Q} 4$ \\
\hline Exploration & & & & & & & & & & & & & & & & & & & & \\
\hline Pilot & & & & & & & & & 一 & & & & & & & & & & & \\
\hline Feasibility & & & & & & & & & & & - & & & & & & & & & \\
\hline Development & & & & & & & & & & & - & & & & & & & & & \\
\hline Gas Buildup & & & & & & & & & & & & & & & & & & - & & \\
\hline Full Production & & & & & & & & & & & & & & & & & & & & \\
\hline
\end{tabular}

Pekerjaan-pekerjaan di atas dapat dilaksanakan pada tahun 2019-2021 (bila regulasi yang lain sesuai dan memungkinkan pekerjaan untuk dimulai), sehingga pengembangan sumur produksi dapat dimulai pada tahun 2021 (Tabel 4).

\subsection{Rencana Pemasaran}

Untuk melakukan pengembangan lapangan dilakukan pendekatan kebutuhan pasar dengan distribusi kebutuhan gas antara lain : a. Diusulkan untuk pembangkit tenaga listrik setempat (Gambar 13).

b. Kemungkinan kebutuhan industri lokal dan rumah tangga.

c. Bila memungkinan dialirkan melalui pipa untuk kebutuhan Perusahaan Gas Negara (PGN) .

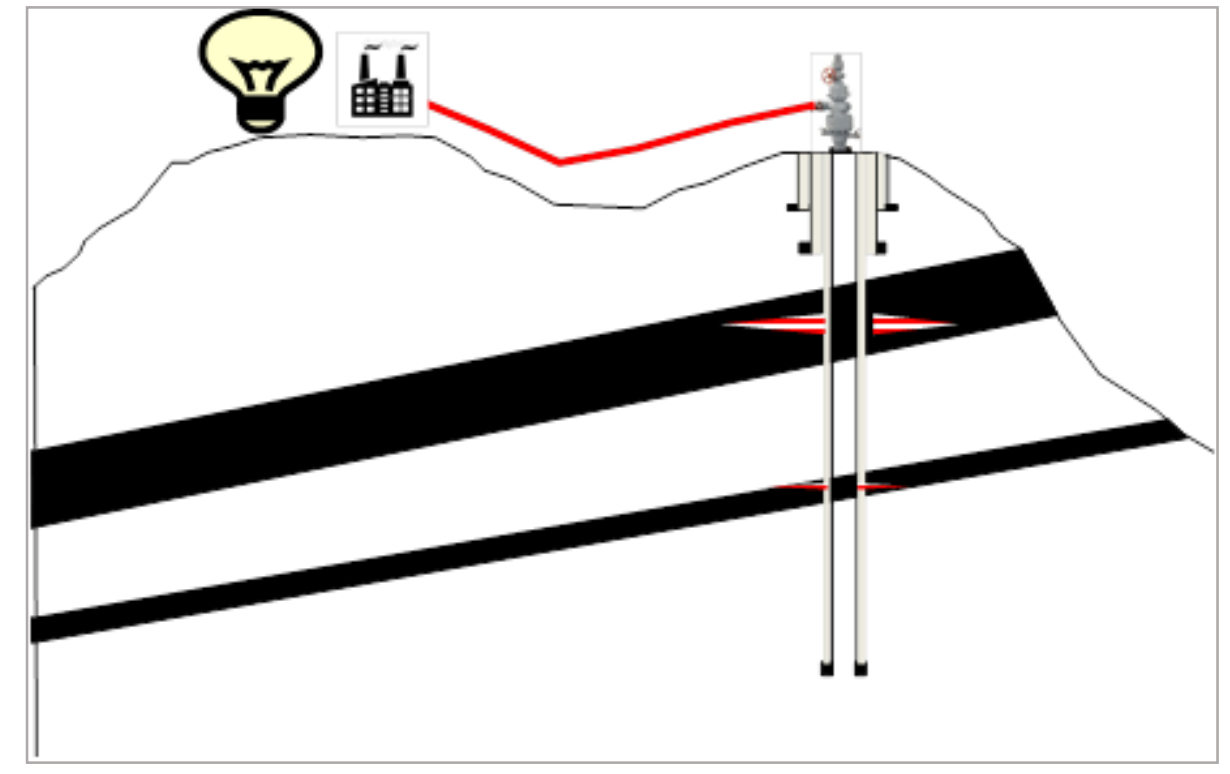

Gambar 13. Gambaran Pemboran Sumur Produksi Gas Metana Batubara Untuk Pembangkit Listrik (Courtesy: Teguh Setiawan, PT. VICO Indonesia)

\section{Kesimpulan}

1. Kandungan Gas (Gas Content) Batubara Daerah Idamanggala, Rantau, Kalimantan Selatan berkisar $5,77-6,72 \mathrm{~m}^{3} /$ ton.

2. Sumberdaya (Gas In Place) Gas Batubara Daerah Idamanggala, Rantau, Kalimantan
Selatan 0,002 TCF dengan kedalaman sumur berkisar 50 - 150 meter.

3. Rencana pengembangan awal lapangan Gas Metana Batubara Daerah Idamanggala, Rantau, Kalimantan Selatan dimulai dari 3 tahun pertama dengan melakukan 5 (lima) sumur pilot. 


\section{Ucapan Terima Kasih}

- PT. Antang Gunung Meratus

- PT. Bumi Rantau Energi

- Hasnur Grup

\section{Daftar Pustaka}

Ayes, W.B., 2002, Coalbed gas systems, resources, and production and a review of contrasting cases from the San Juan and Powder River basins. AAPG Bulletin, 86: 1853-1890.Butland, C.I. and Moore, T.A., in review. Biogenic coal seam gas reservoirs in New Zealand: A preliminary assessment. International Journal of Coal Geology.

Australia Standard AS 3980-1999, 1999, Guide to the determination of gas content of coal Direct desorption method, Standards Association of Australia, $36 \mathrm{p}$.

Badan Geologi, 2012, Potensi dan Pengembangan Coal Bed Methane, Indonesia. ISBN 978602-7928-00-8. Kementerian ESDM.

Basuki Rahmad, Sugeng Raharjo, Eko Widi Pramudiohadi, Ediyanto, 2017. Kajian Sumberdaya Gas Metana Untuk Pengembangan Lapangan Gas Metana Batubara di Daerah Idamanggala, Kec. Sungai Raya, Kab. Hulu Sungai Selatan Kalimantan Selatan Berdasarkan Kualitas dan Mikroskopis Batubara. Seminar Nasional Teknik Kimia "Kejuangan”. ISSN 1693-4393.

Eddy, Greg E,. Rightmire,. Craig, T., Byrer, Charles W., 1982, Relationship of Methane Content of Coal Rank and Depth: Theoretical vs. Observed, Society of Petroleum Engineer, U.S. Dept. of Energy.

Fraillon, M., 2000. The Numerical Modelling of Fluid Flow in Coal as a Porous Media.
Hadiyanto, Stevens, Scott, H., 2004, Coalbed Methane Indicators and Basin Evaluation, Society of Petroleum Engineer.

Kristadi, H.J., Dati, D.W., 2012. Gas Metana Batubara. Pusat Penelitian dan Pengembangan Teknologi Minyak dan Gas Bumi PPTMGB "Lemigas". Kementerian ESDM. ISBN 978-979-8218-26-20.

Moore, Tim, A., 2007, Exploration and Development of a Low Rank, BiogenicallyDerived Coalbed Methane Prospect, Huntly Coalfield, New Zealand, Solid Energy NZ Ltd, Workshop CBM Indonesia, Bali 4-5 July 2007.

Ott, H.L., 1987. The Kutai Basin a Unique Structural History, Proceeding IPA 16th Ann,Conv. p.307-316.

Nelson, C. R., 1999, Effects of Coalbed Reservoir Property Analysis Methods on Gas-InPlaces Estimates, Society of Petroleum Engineer, West Virginia, 21-22 October, 1999.

Stach, E., Mackowsky, M., Th., Teichmuller, M., Tailor, G.H., Chandra, D. \& Techmuller,R., 1982. Stach's Textbook of Coal Petrology 3th edition. Gebr. Borntraeger, BerlinStutgart. p.38-47.

Suarez-Ruiz,I., Crelling,J.C., 2008. Applied Coal . Petrology. The Role of Petrology in Coal Utilization. Elsevier Ltd All rights reserved. 